\title{
Hypothermia for traumatic head injury (Review)
}

\author{
Sydenham E, Roberts I, Alderson P
}

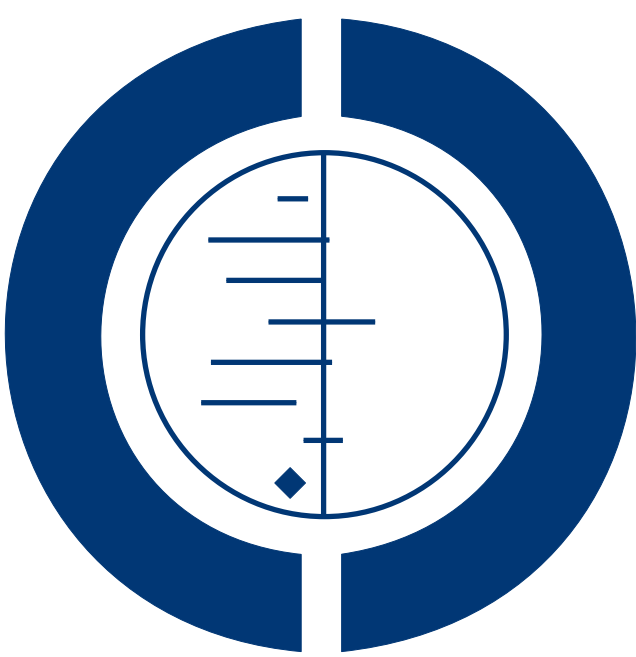

THE COCHRANE COLLABORATION $^{\circledR}$

This is a reprint of a Cochrane review, prepared and maintained by The Cochrane Collaboration and published in The Cochrane Library 2009, Issue 1

http://www.thecochranelibrary.com

\section{WILEY}

Hypothermia for traumatic head injury (Review)

Copyright $\odot 2009$ The Cochrane Collaboration. Published by John Wiley \& Sons, Ltd. 
TABLE OF CONTENTS

HEADER . . . . . . . . . . . . . . . . . . . . . . . . . . . . . . . . . . . . . . . . 1

ABSTRACT . . . . . . . . . . . . . . . . . . . . . . . . . . . . . . . . . . . . . . . . 1

PLAIN LANGUAGE SUMMARY . . . . . . . . . . . . . . . . . . . . . . . . . . . . . . . . . . . . 2

BACKGROUND . . . . . . . . . . . . . . . . . . . . . . . . . . . . . . . . . . . . . . . . .

OBJECTIVES . . . . . . . . . . . . . . . . . . . . . . . . . . . . . . . . . . . . . .

METHODS . . . . . . . . . . . . . . . . . . . . . . . . . . . . . . . . . . . . . . 3

RESULTS . . . . . . . . . . . . . . . . . . . . . . . . . . . . . . . . . . . . . . . . 4

DISCUSSION . . . . . . . . . . . . . . . . . . . . . . . . . . . . . . . . . . . . . 6

AUTHORS' CONCLUSIONS . . . . . . . . . . . . . . . . . . . . . . . . . . . . . . . . . . . .

ACKNOWLEDGEMENTS . . . . . . . . . . . . . . . . . . . . . . . . . . . . . . . . . 6

REFERENCES . . . . . . . . . . . . . . . . . . . . . . . . . . . . . . . . . . . . . . 7

CHARACTERISTICS OF STUDIES . . . . . . . . . . . . . . . . . . . . . . . . . . . . . . . . 10

Hypothermia for traumatic head injury (Review)

Copyright $\odot 2009$ The Cochrane Collaboration. Published by John Wiley \& Sons, Ltd. 


\title{
[Intervention Review]
}

\section{Hypothermia for traumatic head injury}

\author{
Emma Sydenham ${ }^{1}$, Ian Roberts ${ }^{1}$, Phil Alderson ${ }^{2}$ \\ ${ }^{1}$ Cochrane Injuries Group, London School of Hygiene \& Tropical Medicine, London, UK. ${ }^{2}$ National Institute for Health and Clinical \\ Excellence, Manchester, UK \\ Contact address: Emma Sydenham, Cochrane Injuries Group, London School of Hygiene \& Tropical Medicine, Room 280, Keppel \\ Street, London, WC1E 7HT, UK. emma.sydenham@1shtm.ac.uk.
}

Editorial group: Cochrane Injuries Group.

Publication status and date: Edited, conclusions changed, published in Issue 1, 2009.

Review content assessed as up-to-date: 22 May 2008.

Citation: Sydenham E, Roberts I, Alderson P. Hypothermia for traumatic head injury. Cochrane Database of Systematic Reviews 2009, Issue 1. Art. No.: CD001048. DOI: 10.1002/14651858.CD001048.pub3.

Copyright (C) 2009 The Cochrane Collaboration. Published by John Wiley \& Sons, Ltd.

\begin{abstract}
A B S T R A C T
Background

Hypothermia has been used in the treatment of head injury for many years. Encouraging results from small trials and laboratory studies led to renewed interest in the area and some larger trials.
\end{abstract}

\section{Objectives}

To estimate the effect of mild hypothermia for traumatic head injury on mortality and long-term functional outcome complications.

\section{Search strategy}

We searched the Injuries Group Specialised Register, Current Controlled Trials MetaRegister of trials, Zetoc, Web of Knowledge; Science Citation Index [expanded], CENTRAL, MEDLINE and EMBASE. We handsearched conference proceedings and checked reference lists of relevant articles. The search was updated on 23 May 2008.

\section{Selection criteria}

Randomised controlled trials of hypothermia to a maximum of $35^{\circ} \mathrm{C}$ for at least 12 hours versus control in patients with any closed traumatic head injury requiring hospitalisation. Two authors independently assessed all trials.

\section{Data collection and analysis}

Data on death, Glasgow Outcome Scale and pneumonia were sought and extracted, either from published material or by contacting the investigators. Odds ratios (ORs) and 95\% confidence intervals (CIs) were calculated for each trial on an intention-to-treat basis.

\section{Main results}

We found 22 trials with a total of 1409 randomised patients. Twenty trials involving 1382 patients reported deaths. There were fewer deaths in patients treated with hypothermia than in the control group (OR 0.76, 95\% CI 0.60 to 0.97). Eight trials with good allocation concealment showed a non-significant reduction in the likelihood of death for patients treated with hypothermia (OR $0.96,95 \%$ CI 0.68 to 1.35). Twenty trials involving 1382 patients reported data on unfavourable outcomes (death, vegetative state or severe disability). Patients treated with hypothermia were less likely to have an unfavourable outcome than those in the control group (OR 0.69, $95 \%$ CI 0.55 to 0.86 ). Eight trials with good allocation concealment showed a non-significant reduction in the likelihood of unfavourable outcome for patients treated with hypothermia (OR 0.79 , 95\% CI 0.57 to 1.08 ). Hypothermia treatment was associated with an increase in odds of pneumonia but this increase was not statistically significant for trials with good allocation concealment $(3$ trials, 69 patients, OR $1.06,95 \%$ CI 0.38 to 2.97 ).

Hypothermia for traumatic head injury (Review)

Copyright @ 2009 The Cochrane Collaboration. Published by John Wiley \& Sons, Ltd. 


\section{Authors' conclusions}

Hypothermia may be effective in reducing death and unfavourable outcomes for traumatic head injured patients, but significant benefit was only found in low quality trials. Low quality trials have a tendency to overestimate the treatment effect. The high quality trials found some statistically non-significant benefit of hypothermia which could be due to the play of chance. Hypothermia may increase the risk of pneumonia. Due to uncertainties in its effects, hypothermia should only be given to patients taking part in a randomised controlled trial with good allocation concealment.

\section{PLAIN LANGUAGE SUMMARY}

\section{Hypothermia (body temperature cooling) for traumatic head injury}

Twenty-two randomised controlled trials involving 1409 patients with traumatic head injury were included in this review. In each trial, the patients were randomly divided into two groups: one group remained at normal body temperature, and the other group was cooled to a maximum of 35 degrees Celsius for at least 12 hours. Cooling could be of the whole body (e.g. with a blanket with circulating cold water), or just the head (e.g. with a helmet with circulating cold water). Information on death, disability, and pneumonia was evaluated for each trial.

The review authors found that fewer people died or became severely disabled if they were treated with hypothermia, but this finding may be due to the play of chance. It was also found that patients given hypothermia were more likely to develop pneumonia, and some patients died from pneumonia, but the increased risk of pneumonia could also be due to the play of chance.

Some of the trials included in the review were of low methodological quality. Low quality trials have a tendency to overestimate the effect of a treatment. In this review, the lower quality trials showed hypothermia treatment to be effective in reducing death and disability among head injured patients. However, the good quality trials showed less benefit for hypothermia treatment and a lower chance of pneumonia.

The review authors conclude that hypothermia might reduce death and disability in traumatic head injured patients, but it may also increase the risk of pneumonia. These effects may be due to the play of chance. Due to uncertainties in its effects, hypothermia should only be given to patients taking part in good quality randomised controlled trials.

\section{B A C K G R O U N D}

Traumatic head injury is a major cause of death and disability amongst a predominantly young population, with an estimated ten million people experiencing severe head injury worldwide every year (Alexander 1992). There is, however, a significant lack of evidence about effective therapies in the acute care of these patients. A long-term effort to review the literature and produce management guidelines by the American Association of Neurological Surgeons (Bullock 1996; Kirkpatrick 1997) could only make four definitive statements about treatment effectiveness that were supported by strong evidence from randomised studies.

Mild to moderate hypothermia has been used in the treatment of head injury for over 50 years (Fay 1945). Although there were several promising experimental studies (Laskowski 1960; Clasen 1968) and case series (Sedzimir 1959; Shapiro 1974), no controlled clinical studies were performed and the therapy fell from favour. In the last decade, however, several investigators have reported encouraging results of Phase II and III randomised clinical trials (Clifton 1995; Marion 1997; Shiozaki 1993), corroborated by consistent findings of high levels of cerebral protection associated with systemic cooling in well validated laboratory models of global ischaemia (Busto 1987). The early trials were small, singlecentre investigations, which were sufficiently promising to lead on to larger, multi-centre trials.

Whilst the mechanism of action of such temperature control therapy was originally thought to be primarily a reduction in cerebral metabolic rate (Bering 1961), there is now evidence that mild hypothermia might also influence the excessive post-traumatic release of excitatory neurotransmitters (Busto 1989), and attenuate the opening of the blood-brain barrier (Smith 1996). The main risks associated with induced systemic hypothermia are an increased risk of sepsis and pneumonia, coagulation abnormalities, and pos- 
sible myocardial ischaemia and atrial fibrillation (Schubert 1995).

\section{O B J E C T I VE S}

To determine whether the use of mild hypothermia in the treatment of traumatic head injury:

- reduces the risk of death (either during the treatment period or at the end of follow-up);

- reduces the proportion of patients who at final follow-up are either dead, in a vegetative state, or severely disabled;

- increases the risk of pneumonia.

\section{METHODS}

\section{Criteria for considering studies for this review}

\section{Types of studies}

A search was conducted for all randomised controlled trials of mild hypothermia versus control.

\section{Types of participants}

Patients with any closed traumatic head injury requiring hospitalisation.

\section{Types of interventions}

Therapeutic cooling, either locally or systemically, by means of a fluid-filled cooling blanket, a 'bear-hugger' air-cooling device, ice water lavage, any combination of the above, or other methods, to a target temperature of at most $35^{\circ} \mathrm{C}$ for a period of at least 12 consecutive hours. Cooling could begin immediately upon admission to the intensive therapy unit or be deferred until ICP becomes uncontrollable by conventional management.

\section{Types of outcome measures}

\section{Primary outcomes}

- All-cause mortality at the end of the follow-up period.

- Unfavourable outcome at the end of the follow-up period.

Unfavourable outcome was defined as a Glasgow Outcome Scale score of 'severe disability', 'persistent vegetative state', or 'death'; or an equivalent measure if a Glasgow Outcome Score was not presented.

\section{Secondary outcomes}

- The frequency of pneumonia.

\section{Search methods for identification of studies}

None of the searches were restricted by language, date or publication status.

\section{Electronic searches}

For the initial version of the review we searched The Cochrane Injuries Group's Specialised Register in May 1998 for any relevant randomised trials relating to temperature control using the search terms: hypotherm* OR normotherm* OR cool* OR cold* OR temperature.

The search strategy for the register is primarily an electronic search of both MEDLINE and CENTRAL, supplemented by various hand-searching activities listed in the Group details. This was supplemented by a comprehensive EMBASE search, also performed in May 1998, to identify all potential RCTs involving human head injury and temperature control from 1980 onwards. Titles and abstracts from this search were reviewed by David Signorini for possibly relevant trial reports, and the appropriate articles retrieved. The original search strategies can be obtained by contacting the Trials Search Co-ordinator of the Cochrane Injuries Group.

Searches have since been carried out in October 2003, November 2005 and May 2008. The latest search strategies are listed in full in Appendix 1.

\section{Searching other resources}

The searches were supplemented by further handsearching of conference proceedings and abstracts as follows:

- International Conference on Recent Advances in Neurotraumatology, Italy 1996

- 2nd International Neurotrauma Symposium, Glasgow 1993

- 3rd International Neurotrauma Symposium, Toronto 1995

- 4th International Neurotrauma Symposium, Seoul 1997

- 27th Meeting of the Society for Critical Care Medicine, USA 1998

- 10th International Symposium on Intracranial Pressure, USA 1997

In addition, reference lists of all relevant trials and review articles were checked, and leading investigators in the field were contacted for information about any other published or unpublished trials which may have been overlooked.

\section{Data collection and analysis}




\section{Selection of studies}

The results of the search were screened by ES and IR. The full text of relevant records were obtained. Both authors independently compared the trial design with the inclusion criteria for this review. Disagreements were resolved by discussion.

\section{Data extraction and management}

The following information was extracted from each trial: method of allocation concealment, blinding of outcome assessment, number of randomised patients, death or severe disability at various times during follow up, treatment duration, duration of follow up, loss to follow up, and number of patients with pneumonia during the treatment period. This information was extracted and entered into Review Manager (RevMan) by ES; IR checked for accuracy. Trial report authors were contacted for additional information or clarification.

\section{Assessment of risk of bias in included studies}

Quality of allocation concealment was assessed by the review authors on the following scale (Higgins 2008):

- Yes: low risk of bias (e.g. sequentially numbered, sealed, opaque envelopes)

- No: high risk of bias (e.g. day of the week)

- Unclear: unclear or unknown risk of bias (method not stated).

\section{Data synthesis}

Mantel-Haenzel odds ratios (ORs) and 95\% confidence intervals (CIs) were calculated for death, pneumonia, and unfavourable outcomes for each trial on an intention-to-treat basis. The odds ratio was chosen because of the large variation in baseline event rates between the trials (mortality in the control groups ranges from $0 \%$ to $82 \%$ ), implying that the relative risk would not be a good summary measure. Also, the Mantel-Haenzel approach was used because of the inaccuracy of Peto's approximation when the estimated treatment effect is large, as it was in several of the trials considered. Heterogeneity of treatment effect between trials was assessed using a standard chi-square test, $\mathrm{I}^{2}$, and if appropriate, a weighted estimate of the typical treatment effect across all studies was calculated.

\section{Subgroup analysis and investigation of heterogeneity}

Subgroup analyses were performed to determine whether the treatment effect varies with: a) trial quality (quality of allocation concealment), b) duration of hypothermia, and c) length of followup.

\section{RE S U L T S}

\section{Description of studies}

See: Characteristics of included studies; Characteristics of excluded studies; Characteristics of studies awaiting assessment; Characteristics of ongoing studies.

\section{Results of the search}

A total of 22 randomised controlled trials were identified that met the inclusion criteria.

\section{Included studies}

The 22 included randomised controlled trials involved 1409 randomised patients. All trials except two (Ishikura 1998, Meissner 2003a) reported the number of deaths in the intervention and control groups at final follow-up. Fourteen trials reported GOS scores specifically at three, six or 12 months post-injury. The occurrence of pneumonia was reported in ten trials.

\section{Risk of bias in included studies}

\section{Allocation}

Adequate allocation concealment is an important dimension of trial quality.

Eight trials had a reasonable standard of allocation concealment (Adelson 2005 HYPO1; Adelson 2005 HYPO2; Clifton 1992; Clifton 1993; Clifton 2001; Marion 1997; Meissner 1998; Qiu 2007). Twelve trials had unclear allocation concealment (e.g. 'by lot') (Aibiki 2000; Biswas 2002; Hashiguchi 2003; Hirayama 1994; Jiang 2000; Meissner 2003b; Shiozaki 1993; Shiozaki 1999; Shiozaki 2001; Smrcka 2005; Yan 2001; Zhang 2000). Two trials did not present mortality or GOS data in the treatment and control groups (Ishikura 1998; Meissner 2003a) and had unclear allocation concealment.

\section{Effects of interventions}

\section{Death at final follow-up}

Analysis 1.1

Twenty trials involving 1382 patients reported deaths. Patients treated with hypothermia were less likely to die than those in the control group (OR $0.76,95 \%$ CI 0.60 to 0.97 ). There was no evidence of statistical heterogeneity between trials $\left(\mathrm{Chi}^{2}=15.53\right.$, $\left.\mathrm{df}=18(\mathrm{P}=0.63) ; \mathrm{I}^{2}=0 \%\right)$.

Hypothermia for traumatic head injury (Review)

Copyright @ 2009 The Cochrane Collaboration. Published by John Wiley \& Sons, Ltd. 


\section{Death at final follow-up stratified by trial quality}

Analysis 1.2

Concealed allocation was reported in 8 studies involving 686 patients. Hypothermia treatment was associated with a statistically non-significant reduction in death compared with the control group (OR $0.96,95 \%$ CI 0.68 to 1.35 ). There was no evidence of statistical heterogeneity between trials $\left(\mathrm{Chi}^{2}=1.01, \mathrm{df}=7(\mathrm{P}\right.$ $\left.=0.99) ; \mathrm{I}^{2}=0 \%\right)$.

Non-concealed allocation, or 'unclear' concealment according to Higgins 2008, was reported in 12 studies involving 696 patients. Patients treated with hypothermia were less likely to die than those in the control group (OR $0.62,95 \%$ CI 0.44 to 0.86 ). There was no evidence of statistical heterogeneity between trials $\left(\mathrm{Chi}^{2}=\right.$ $\left.11.14, \mathrm{df}=10(\mathrm{P}=0.35) ; \mathrm{I}^{2}=10 \%\right)$.

\section{Unfavourable outcome at final follow-up}

Analysis 1.3

Twenty trials involving 1382 patients reported death or severe disability. Patients treated with hypothermia were less likely to have an unfavourable outcome than those in the control group (OR $0.69,95 \%$ CI 0.55 to 0.86 ). There was some evidence of statistical heterogeneity between trials $\left(\mathrm{Chi}^{2}=30.71, \mathrm{df}=19(\mathrm{P}=\right.$ $\left.0.04) ; \mathrm{I}^{2}=38 \%\right)$.

\section{Unfavourable outcome stratified by trial quality}

Analysis 1.4

Concealed allocation was reported in 8 studies involving 686 patients. Hypothermia treatment was associated with a statistically non-significant reduction in death compared with the control group (OR $0.79,95 \%$ CI 0.57 to 1.08$)$. There was no statistical heterogeneity between trials $\left(\mathrm{Chi}^{2}=4.79, \mathrm{df}=7(\mathrm{P}=0.69) ; \mathrm{I}^{2}=\right.$ $0 \%)$.

Non-concealed allocation, or 'unclear' concealment according to Higgins 2008, was reported in 12 studies involving 696 patients. Patients treated with hypothermia were less likely to have an unfavourable outcome than those in the control group (OR 0.60, $95 \%$ CI 0.44 to 0.82$)$. There was some statistical heterogeneity between trials $\left(\mathrm{Chi}^{2}=24.64, \mathrm{df}=11(\mathrm{P}=0.01) ; \mathrm{I}^{2}=55 \%\right)$.

\section{Unfavourable outcome stratified by treatment duration}

Analysis 1.5

Twelve trials reported deaths or severe disability according to the duration of treatment.

Two trials involving 91 patients treated patients in the hypothermia group for 24 hours. Patients in the hypothermia group were less likely to have an unfavourable outcome than those in the control group (OR $0.38,95 \%$ CI 0.16 to 0.90 ). There was no statistical heterogeneity between these two trials $\left(\mathrm{Chi}^{2}=0.00, \mathrm{df}=1\right.$ $\left.(\mathrm{P}=0.99) ; \mathrm{I}^{2}=0 \%\right)$.
Ten trials involving 683 patients treated patients in the hypothermia group for 48 hours. Hypothermia treatment was associated with a statistically non-significant reduction in unfavourable outcome compared with the control group (OR 0.96, 95\% CI 0.70 to 1.31). There was no statistical heterogeneity between trials $\left(\mathrm{Chi}^{2}\right.$ $\left.=12.13, \mathrm{df}=9(\mathrm{P}=0.21) ; \mathrm{I}^{2}=26 \%\right)$.

\section{Unfavourable outcome at various times during follow-up}

Analysis 1.6

Fourteen trials reported GOS scores at three, six or 12 months post-injury. Some trials reported GOS scores at more than one time point.

Six trials involving 271 patients reported GOS scores at three months post-intervention. Hypothermia treatment was associated with a statistically non-significant reduction in death compared with the control group (OR 0.85 , 95\% CI 0.52 to 1.39 ). There was some statistical heterogeneity between trials $\left(\mathrm{Chi}^{2}=10.29, \mathrm{df}\right.$ $\left.=5(\mathrm{P}=0.07) ; \mathrm{I}^{2}=51 \%\right)$.

Eight trials involving 634 patients reported GOS scores at six months post-intervention. Patients treated with hypothermia were less likely to have an unfavourable outcome than those in the control group (OR $0.62,95 \%$ CI 0.45 to 0.86 ). There was significant statistical heterogeneity between trials $\left(\mathrm{Chi}^{2}=21.55, \mathrm{df}=7(\mathrm{P}=\right.$ $0.003) ; \mathrm{I}^{2}=68 \%$ ).

Four trials involving 262 patients reported GOS scores at 12 months post-intervention. Patients treated with hypothermia were less likely to have an unfavourable outcome than those in the control group (OR $0.52,95 \%$ CI 0.31 to 0.87 ). There was no statistical heterogeneity between trials $\left(\mathrm{Chi}^{2}=3.62, \mathrm{df}=3(\mathrm{P}=0.31)\right.$; $\left.\mathrm{I}^{2}=17 \%\right)$.

\section{Pneumonia during the treatment period}

\section{Analysis 1.7}

Ten trials involving 322 patients reported pneumonia cases. Patients treated with hypothermia were more likely to have pneumonia than those in the control group (OR 2.06, 95\% confidence interval 1.28 to 3.30 ).

Pneumonia was stratified by trial quality:

Three trials with good allocation concealment involving $69 \mathrm{pa}-$ tients reported pneumonia cases. Hypothermia treatment was associated with a statistically non-significant increase in pneumonia (OR 1.06, 95\% confidence interval 0.38 to 2.97 ). There was no statistical heterogeneity between trials $\left(\mathrm{Chi}^{2}=0.55, \mathrm{df}=2(\mathrm{P}=\right.$ $0.76) ; \mathrm{I}^{2}=0 \%$ ).

Seven trials with non-concealed allocation involving 253 patients reported pneumonia cases. Patients treated with hypothermia were more likely to have pneumonia than those in the control group (OR 2.47, 95\% confidence interval 1.44 to 4.23 ). There was no statistical heterogeneity between trials $\left(\mathrm{Chi}^{2}=9.34, \mathrm{df}=5(\mathrm{P}=\right.$ $\left.0.10) ; \mathrm{I}^{2}=46 \%\right)$. 


\section{DISCUSSION}

\section{Summary of main results}

Hypothermia may be effective in reducing death and unfavourable outcomes for traumatic head injured patients, but significant benefit was only found in low quality trials. The high quality trials found some statistically non-significant benefit of hypothermia which could be due to the play of chance. Hypothermia may increase the risk of pneumonia. Due to uncertainties in its effects, hypothermia should only be given to patients taking part in a randomised controlled trial with good allocation concealment.

\section{Quality of the evidence}

Numerous trials of hypothermia treatment have been conducted in recent years. The majority of trials found were of low quality, with unclear allocation concealment. These low quality trials may overestimate the effectiveness of hypothermia treatment versus control.

Trials with good allocation concealment showed a smaller treatment effect which may be due to the play of chance. The increased incidence of pneumonia was not statistically significant in trials with good allocation concealment.

\section{Potential biases in the review process}

This systematic review addresses a focused research question using predefined inclusion criteria and methodology to select and appraise eligible studies.

As with all systematic reviews, the possibility of publication bias should be considered as a potential threat to validity. However, in light of our extensive and sensitive searching we believe that the risk of such a bias affecting the results is minimal.

The majority of trials found or included in the review were of low methodological quality. An additional ten trials with unclear methods of randomisation or allocation concealment were identified, and are awaiting assessment until clarification is obtained from the trial report authors.

\section{Agreements and disagreements with other studies or reviews}

The conclusions of this review are broadly consistent with those of Peterson 2008. The majority of trials identified for this review and Peterson 2008 were of low methodological quality. Both reviews found there may be an increased likelihood of pneumonia with hypothermia.

\section{A U THORS, CONCLUSIONS}

\section{Implications for practice}

Hypothermia may be effective in reducing death and unfavourable outcomes for traumatic head injured patients, but significant benefit was only found in low quality trials. Low quality trials have a tendency to overestimate the treatment effect. The high quality trials found some statistically non-significant benefit of hypothermia which could be due to the play of chance. Hypothermia may increase the risk of pneumonia. Due to uncertainties in its effects, hypothermia should only be given to patients taking part in a randomised controlled trial with good allocation concealment.

\section{Implications for research}

More high quality randomised controlled trials are needed to determine the benefit of hypothermia for traumatic head injury.

\section{ACKNOW LEDGEMENTS}

Thanks to:

- Brenda Thomas (Stroke Review Group) for help and advice with the original EMBASE search strategy.

- Ian Whittle, Kate Signorini, Elena Telaro, Yoichi Nagayama, Irene Kwan, Frank Del Vecchio, Lisa Xue and Cynthia To for help with manuscripts in languages other than English.

- Reinhard Wentz and Irene Kwan of the Injuries Group for the original searches.

- Katharine Ker of the Injuries Group for work on previous versions of the review.

- Karen Blackhall, Trials Search Co-ordinator of the Cochrane Injuries Group for updating the searches in 2003, 2005 and 2008. 


\section{R E F E R E N C E S}

\section{References to studies included in this review}

Adelson 2005 HYPO1 \{published data only\} Adelson PD, Ragheb J, Muizelaar JP, Kanev P, Brockmeyer $\mathrm{D}$, Beers $\mathrm{S}$, et al.Phase II clinical trial of moderate hypothermia after severe traumatic brain injury in children. Neurosurgery 2005;56(4):740-54. [DOI: 10.1227/ 01.NEU.0000156471.50726.26]

Adelson 2005 HYPO2 \{published data only\} Adelson PD, Ragheb J, Muizelaar JP, Kanev P, Brockmeyer $\mathrm{D}$, Beers $\mathrm{S}$, et al.Phase II clinical trial of moderate hypothermia after severe traumatic brain injury in children. Neurosurgery 2005;56(4):740-54. [DOI: 10.1227/ 01.NEU.0000156471.50726.26]

Aibiki 2000 \{published data only\}

Aibiki M, Maekawa S, Yokono S. Moderate hypothermia improves imbalances of thromboxane $\mathrm{A} 2$ and prostaglandin I2 production after traumatic brain injury in humans. Critical Care Medicine 2000;28(12):3902-6.

Biswas 2002 \{published data only\}

Biswas AK, Bruce DA, Sklar FH, Bokovoy JL, Sommerauer JF. Treatment of acute traumatic brain injury in children with moderate hypothermia improves intracranial hypertension. Critical Care Medicine 2002;30(12): 2742-51. [DOI: 10.1097/01.CCM.000038209.56308.9E]

Clifton 1992 \{published and unpublished data\} Clifton GL, Allen S, Berry J, Koch SM. Systemic hypothermia in treatment of brain injury. Journal of Neurotrauma 1992;9:S487-95.

Clifton 1993 \{published data only\}

Clifton GL. Hypothermia and hyperbaric oxygen as treatment modalities for severe head injury. New Horizons 1995;3:474-8.

Clifton GL. Hypothermia in the management of patients with head injury. Abstracts of the 2nd International Neurotrauma Symposium. Glasgow, 1993; Vol. July 4-9. Clifton GL. Systemic hypothermia in treatment of severe brain injury. Journal of Neurosurgical Anesthesiology 1995;7: 152-6.

Clifton GL. Systemic hypothermia in treatment of severe brain injury: A review and update. Journal of Neurotrauma 1995;12:923-7.

* Clifton GL, Allen S, Barrodale P, Plenger P, Berry J, Koch S, Fletcher J, Hayes RL, Choi SC. A phase II study of moderate hypothermia in severe brain injury. Journal of Neurotrauma 1993;10:263-73.

Clifton 2001 \{published data only\}

Clifton GL. Hypothermia in Neurotrauma. Abstracts of the 3rd International Neurotrauma Symposium. Toronto, Canada, 1995:July 22-27.

* Clifton GL, Miller ER, Choi SC, Levin HS, McCauley S, Smith KR, et al.Lack of effect of induction of hypothermia after acute brain injury. New England Journal of Medicine 2001;344(8):556-63.
Hashiguchi 2003 \{published data only\}

Hashiguchi N, Shiozaki T, Ogura H, Tanaka H, Koh T, Noborio $\mathrm{M}$, et al.Mild hypothermia reduces expression of heat shock protein 60 in leukocytes from severely headinjured paitents. The Journal of Trauma Injury, Infection, and Critical Care 2003;55:1054-60. [DOI: 10.1097/ 01.TA.0000033252.43742.8B]

Hirayama 1994 \{published data only\}

Hayashi N, Hirayama T, Udagawa A, Daimon W, Ohata M. Systemic Management of Cerebral Edema Based on a New Concept in Severe Head Injury Patients. Acta Neurochir 1994;60(supplement):541-3.

Hayashi N, Shibuya T, Kinoshita K, Jo S, Azuhata T, Mera K, Tanjo K. The cerebral thermal dysregulation and hypothermia treatment in severe brain injury patients. Abstracts of the Tenth International Symposium on Intracranial Pressure and Neuromonitoring in Brain Injury. Williamsburg USA, 1997:May 25-29.

* Hirayama T, Katayama Y, Kano T, Hayashi N, Tsubokawa T. Impact of Moderate Hypothermia on Therapies for Intracranial Pressure Control in Severe Traumatic Brain Injury. In: Nagai H, Ishii S, Maeda M editor(s). Intracranial Pressure IX. Tokyo: Springer-Verlag, 1994:233-6.

Hirayama T, Katayama Y, Maeda T, Kawamata T, Tsubokawa T. Effects of moderate hypothermia on the evolution of cerebral contusion. Abstracts of the 3rd International Neurotrauma Symposium. Toronto, Canada, 1995:July 22-27.

Ishikura 1998 \{published data only\}

* Ishikura H, Yamagami K, Akahori M, Shoji Y, Fukui H, Tanaka T. Changes in Blood Platelet Count and Serum Thrombopoetin (TPO) level under Moderate Hypothermic Therapy in Traumatic Severe Closed Head Injury. Critical Care Medicine 1998;26(Supplement 1):A82.

Jiang 2000 \{published data only\}

* Jiang JY, Yu MK, Zhu C. Effect of long-term mild hypothermia therapy in patients with severe traumatic brain injury: 1-year follow-up review of 87 cases. Journal of Neurosurgery 2000;93:546-9.

Jiang JY, Zhu C. The mild hypothermia significantly decreases mortality of severe traumatic brain injured patients. Abstracts of the International Conference on Recent Advances in Neurotraumatology, Riccione, Italy, Sept 8-11 1996. 1996.

\section{Marion 1997 \{published data only\}}

Clark RSB, Kochanek PM, Obrist WD, Wong HR, Billiar TR, Wisniewski SR, Marion DW. Cerebrospinal fluid and plasma nitrite and nitrate concentrations after head injury in humans. Critical Care Medicine 1996;24:1243-51. Darby JM, Marion DW, Peitzman A, Carlier P, Obrist WD. Pulmonary complications in brain-injured patients treated with hypothermia. Anesthesiology 1992;77:A295.

Marion DW, Carlier P. Moderate therapeutic hypothermia improves outcome following severe traumatic brain 
injury. Abstracts of the 3rd International Neurotrauma Symposium. Toronto, Canada, 1995:July 22-27. Marion DW, Obrist WD, Carlier PM, Penrod LE, Darby JM. The use of moderate therapeutic hypothermia for patients with severe head injuries: a preliminary report. Journal of Neurosurgery 1993;79:354-62.

Marion DW, Palmer AM, DeKosky ST, Kochanek PM, Carlier PM. Effect of moderate hypothermia on neurochemical mediators of secondary brain injury. Journal of Neurosurgery 1995;82:344A.

Marion DW, Penrod LE, Kelsey SF, Obrist WD, Kochanek PM, Palmer AM, Wisniewski SR, DeKosky ST. Treatment of traumatic brain injury with moderate hypothermia. Abstracts of the Tenth International Symposium on Intracranial Pressure and Neuromonitoring in Brain Injury. Williamsburg USA, 1997:May 25-29.

* Marion DW, Penrod LE, Kelsey SF, Obrist WD, Kochanek PM, Palmer AM, Wisniewski SR, DeKosky ST. Treatment of traumatic brain injury with moderate hypothermia. New England Journal of Medicine 1997;336:540-6.

Resnick DK, Marion DW, Darby JM. The effect of hypothermia on the incidence of delayed traumatic intracerebral hemorrhage. Neurosurgery 1994;34:252-6.

Meissner 1998 \{published and unpublished data\} Meissner W, Fritz H, Dohrn B, Specht M, Reinhart K. Influence of Hypothermia on Cytokine Concentrations in Head Injured Patients. Critical Care Medicine 1998;26 (Supplement 1):A82.

Meissner 2003a \{published data only\} Meissner W, Fritz H, Dohm B, Krapp C, Reinhart K. Hormonal and haemodynamic consequences of moderate hypothermia in head injured patients. Neurosciences 2003: 102-3.

Meissner 2003b \{published data only\} Meissner W, Krapp C, Kauf E, Dohrn B, Reinhart K. Thyroid hormone response to moderate hypothermia in severe brain injury. Intensive Care Medicine 2003;29:44-8. [DOI: 10.1007/s00134-002-1556-3]

Qiu 2007 \{published data only\} Qiu W, Zhang Y, Sheng H, Zhang J, Wang W, Liu W, et al.Effects of therapeutic mild hypothermia on patients with severe traumatic brain injury after craniotomy. Journal of critical care 2007;22:229-36.

Shiozaki 1993 \{published and unpublished data\} Shiozaki T, Sugimoto H, Taneda M, Yoshida H, Iwai A, Yoshioka T, Sugimoto T. Effect of mild hypothermia on uncontrollable intracranial hypertension after severe head injury. Journal of Neurosurgery 1993;79:363-8.

Shiozaki 1999 \{published data only\} Shiozaki T, Kato A, Taneda M, Hayakata T, Hashiguchi N, Tanaka H. Little benefit from mild hypothermia therapy for severely head injured patients with low intracranial pressue. Journal of Neurosurgery 1999;91:185-91.

Shiozaki 2001 \{published data only\} Shiozaki T, Hayakata T, Taneda M, Nakajima Y, Hashiguchi N, Fujimi S, et al.A multicenter prospective randomized controlled trial of the efficacy of mild hypothermia for severely head injured patients with low intracranial pressure. Journal of Neurosurgery 2001;94:50-4.

Smrcka 2005 \{published data only\} Smrcka M, Vidlak M, Maca K, Smrcka V, Gal R. The influence of mild hypothermia on ICP, CPP and outcome in patients with primary and secondary brain injury. Acta Neurochir 2005;95(Suppl):273-5.

Yan 2001 \{published data only\}

Yan Y, Tang W. Changes of evoked potentials and evaluation of mild hypothermia for treatment of severe brain injury. Chinese Journal of Traumatology 2001;4:8-13.

Zhang 2000 \{published data only\}

Zhang K, Wang JX. Comparative study on mild hypothermia in patients with severe head injury and the most severe head injury. Inner Mongolia Medical Journal 2000;32:4-6.

\section{References to studies excluded from this review}

\section{Chouhan 2006 \{published data only\}}

Chouhan RS, Dash HH, Bithal PK, Chaturvedi A, Pandia MP, Radhakrishnan M, et al.Intraoperative mild hypothermia for brain protection during intracranial aneurysm surgery. J Anaesth Clin Pharmacol 2006;22(1): 21-8.

Fukuoka 2004 \{published data only\} Aibiki M. Personal communication with author. September 10, 2008.

* Fukuoka N, Aibiki M, Tsukamoto T, Seki K, Morita S. Biphasic concentration change during continuous midazolam administration in brain-injured patients undergoing thapeutic moderate hypothermia. Resuscitation 2004;60:225-30.

Gentilello 1997 \{published data only\}

Gentilello LM, Jurkovich GJ, Stark MS, Hassantash SA, O'Keefe GE. Is hypothermia in the victim of major trauma protective or harmful?. Annals of Surgery 1997;226:439-49.

Hayashi 2002 \{published data only\}

Hayashi S, Inao S, Takayasu M, Kajita Y, Ishiyama J, et al.Effect of early induction of hypothermia on severe head injury (abstract). Acta Neurochir Suppl 2002;81:83-4. [PUBMED: 12168365]

\section{Hayashi 2005 \{published data only\}} Hayashi S, Takayasu M, Inao S, Yoshida J. Balance of risk of therapeutic hypothermia. Acta Neurochir 2005;95(Suppl): 269-72.

Legros 1985 \{published data only\}

Legros B, Lapierre F, Laudat P, Krettly PH, Fournier $\mathrm{P}$, Meny J, et al.Barbiturate hypothermia treatment for post-traumatic brain injury:infectious complications and mortality [Barbiturici-ipotermia nella protezione metabolica cerebrale post-traumatica: complicazioni infettive e mortalita]. Minerva Anesthesiologica 1985;51: 525-30. 
Liu 2005 \{published data only\}

Liu W, An Y-H, Liu E-Z, Yu C-J. Effect of mild hypothermia combined with hibernation on the homeostasis of patients with severe head injury. Chinese Journal of Clinical Rehabilitation 2005;9(33):175-7.

Liu 2006 \{published data only\}

Liu WG, Qiu WS, Zhang Y, Wang WM, Lu F, Yang XF. Effects of selective brain cooling in patients with severe traumatic brain injury: a preliminary study. The Journal of International Medical Research 2006;34:58-64.

Nara 1997 \{published data only\}

Nara I, Shiogai T, Saruta K, Hara M, Saito I. Comparative effects of hypothermia, barbituates, and osmotherapy for cerebral oxygen metabolism, intracranial pressure and cerebral perfusion pressure in patients with severe head injury. Abstracts of the Tenth International Symposium on Intracranial Pressure and Neuromonitoring in Brain Injury. Williamsburg USA, 1997:May 25-29.

Nordby 1984 \{published data only\} Nordby HK, Nesbakken R. The effect of high-dose barbituate compression after severe head Injury: a controlled clinical trial. Acta Neurochirurgica 1984;72:157-66.

Schulman 2005 \{published data only\} Schulman C, Namias N, Doherty J, Manning R, Li P, Alhaddad A, et al.The effect of antipyretic therapy upon outcomes in critically ill patients: a randomized, prospective study. Surgical interventions 2005;6(4):369-75.

Shen 2000 \{published data only\}

Shen JH, Shen MW. Application of mild hypothermia in treatment of severe brain injury. Heibei Med J 2000;6: 498-500.

Wusi 2006 \{published data only\}

Wusi Q, Hong S, Ying Z, Weimin W, Weiguo L, Qizhou $\mathrm{J}$, et al.Noninvasive selective brain cooling by head and neck cooling is protective in severe traumatic brain injury. Journal of Clinical Neuroscience 2006;13:995-1000.

Yamagami 1997 \{published data only\}

Yamagami K, Iwase M, Matsubara M, Matsuo N, Tanaka $\mathrm{T}$. Nitric oxide production and arginine consumption in traumatic brain injury are correlated with severity. Abstracts of the 26th Meeting of the Society for Critical Care Medicine. Critical Care Medicine. 1997; Vol. 25, issue supplement 1:A72.

\section{References to studies awaiting assessment}

\section{Chen 2001 \{published data only\}}

Chen L, Piao Y, Zeng F, Lu M, Kuang Y, Li X. Moderate hypothermia therapy for patients with severe head injury. Chinese Journal of Traumatology (English edition) 2001;4(3): 164-7.

Guo 2004 \{published data only\} Guo W, Wang L-L, Cai K-H. A control study on mild hypothermia in treatment of severe craniocerebral injury. Journal of Xinxiang Medical College 2004;21(4):269-71.
Hutchison 2008 \{published data only\}

Hutchison J, Ward R, Lacroix J, Hebert P, Barnes M, et al.Hypothermia therapy after traumatic brain injury in children. The New England Journal of Medicine 2008;358: 2447-56.

Mrlian 2006 \{published data only\}

Mrlian A, Smrcka M, Klabusay M. The use of controlled mild hypothermia and immune system status in patients with severe brain injury. Bratisl Lek Listy 2006;107(4): $113-7$.

Qiu 2005 \{published data only\} Qiu WS, Liu WG, Shen H, Wang WM, Zhang SL, Zhang $\mathrm{Y}$, et al.Therapeutic effect of mild hypothermia on severe traumatic head injury. Chinese Journal of Traumatology 2005;8(1):27-32.

Qiu 2006 \{published data only\} Qiu W, Wang W, Du H, Liu W, Shen H, Shen L, et al.Thrombocytopenia after therapeutic hypothermia in severe traumatic brain injury. Chinese Journal of Traumatology 2006;9(4):238-41.

Wang 2005 \{published data only\} Wang WP, Ren HJ, Chi JY, Xu FL, Quan Y. Effects of mild hypothermia on patients with lower intracranial pressure following severe brain injury. Chinese Journal of Traumatology 2005;8(1):54-6.

Wang 2007 \{published data only\} Wang Q, Li AL, Zhi DS, Huang HL. Effect of mild hypothermia on glucose metabolism and glycerol of brain tissue in patients with severe traumatic brain injury. Chinese Journal of Traumatology 2007;10(4):246-9.

Xia 2005 \{published data only\} Xia YQ, Yan LL, Xu RX, Wang QH. Evaluation of improvement of subhypothermia in cerebral vasospasm after severe craniocerebral injury. Chinese Journal of Clinical Rehabilitation 2005;9(41):138-41.

Yan 2007 \{published data only\} Yan Y, Tang W, He J, Gao J, Dan W, Zhong D, et al.Clinical research about brain oxygen metabolism and neuroelectrophysiology during mild hypothermia in patients with severe head injury. Chinese Journal of Surgery 2007;45(2):109-13.

Zhi 2003 \{published data only\}

Zhi D, Zhang S, Lin X. Study on the therapeutic mechanism and clinical effect of mild hypothermia in patients with severe head injury. Surg Neurol 2003;59:381-5. [DOI: 10.1016/S0090-3019(03)00148-4]

\section{References to ongoing studies}

Adelson 2007 \{unpublished data only\}

Pediatric traumatic brain injury consortium: hypothermia. Ongoing study November 2007.

Clifton 2002 \{unpublished data only\} National Acute Brain Injury Study: Hypothermia II (NABISH II). Ongoing study 4/1/02 - 6/30/08. 


\section{Additional references}

\section{Adelson 2008a}

Adelson D. [Personal communication with author]. 5

October 2008

\section{Adelson 2008b}

Adelson D. [Personal communication with author]. 17 October 2008

\section{Alexander 1992}

Alexander E Jr. Global Spine and Head Injury Prevention Project (SHIP). Surgical Neurology 1992;38:478-9.

\section{Bering 1961}

Bering EA Jr. Effect of body temperature change on cerebral oxygen consumption of the intact monkey. American Journal of Physiology 1961;200:417-9.

\section{Bullock 1996}

Bullock R, Chesnut RM, Clifton G, Ghajar J, Marion DW, Narayan RK, et al.Guidelines for the management of severe head injury. Journal of Neurotrauma 1996;13:639-734.

\section{Busto 1987}

Busto R, Dietrich WD, Globus MY, Valdes I, Scheinberg P, Ginsberg MD. Small differences in intra-ischemic brain temperature critically determine the extent of ischemic neuronal injury. Journal of Cerebral Blood Flow Metabolism 1987;7:729-38.

\section{Busto 1989}

Busto R, Globus MY, Dietrich WD, Martinez E, Valdes I, Ginsberg MD. Effect of mild hypothermia on ischemiainduced release of neuro-transmitters and free fatty acids in rat brain. Stroke 1989;20:904-10.

\section{Clasen 1968}

Clasen RA, Pandolfi S, Russell J, Stuart D, Hass GM Hypothermia and hypotension in experimental cerebral edema. Archives of Neurology 1968;19:472-86.

\section{Clifton 1995}

Clifton GL. Systemic Hypothermia in Treatment of Severe Brain Injury: A Review and Update 1995. Journal of Neurotrauma 1995;12:923-7.
Fay 1945

Fay T. Observations on generalized refrigeration in cases of severe cerebral trauma. Assoc Res Nerv Ment Dis Proc 1945; 24:611-19

\section{Higgins 2008}

Higgins JPT, Green S (editors). The Cochrane Handbook of Systematic Reviews. The Cochrane Collaboration 2008; Vol. Version 5.0.0 [updated February 2008]:Available from www.cochrane-handbook.org.

\section{Kirkpatrick 1997}

Kirkpatrick PJ. On guidelines for the management of severe head injury. Journal of Neurology, Neurosurgery and Psychiatry 1997;62:109-11.

\section{Laskowski 1960}

Laskowski EJ, Klato I, Baldwin M. Experimental sutdy on the effects of hypothermia on local brain injury. Neurology 1960;10:499-505.

\section{Peterson 2008}

Peterson K, Carson S, Carney N. Hypothermia treatmen for traumatic brain inury: a systematic review and metaanalysis. Journal of Neurotrauma 2008;25:62-71. [DOI: 10.1089/neu.2007.0424]

\section{Review Manager (RevMan)}

The Nordic Cochrane Center. Review Manager (RevMan). 5.0.0. Copenhagen: The Cochrane Collaboration, 2008.

\section{Schubert 1995}

Schubert A. Side effects of mild hypothermia. Journal of Neurosurgical Anesthesiology 1995;7:139-47.

\section{Sedzimir 1959}

Sedzimir CB. Therapeutic hypothermia in cases of head injury. Journal of Neurosurgery 1959;16:407-14.

\section{Shapiro 1974}

Shapiro HM, Wyte SR, Loeser J. Barbiturate-augmented hypothermia for reduction of persistent intracranial hypertension. Journal of Neurosurgery 1974;40:90-100.

\section{Smith 1996}

Smith SL, Hall ED. Mild pre- and posttraumatic hypothermia attenuates blood-brain barrier damage following controlled cortical impact injury in the rat. Journal of Neurotrauma 1996;13:1-9.

* Indicates the major publication for the study 


\section{CHARACTERISTICS OF STUDIES}

\section{Characteristics of included studies [ordered by study [D]}

\section{Adelson 2005 HYPO1}

\begin{tabular}{|c|c|}
\hline Methods & Multicentre, randomised, controlled trial. \\
\hline Participants & Patients less than 13 years of age, with a GOS of 8 or less. \\
\hline Interventions & $\begin{array}{l}\text { Hypothermia patients: Cooling to } 32-33 \mathrm{C} \text { within } 6 \text { hours of injury for } 48 \text { hours. Passively rewarmed by } \\
1 \mathrm{C} \text { every } 3-4 \text { hours. } \\
\text { Normothermia patients: no intervention/not reported. }\end{array}$ \\
\hline Outcomes & $\begin{array}{l}\text { ICP } \\
\text { CPP } \\
\text { Mortality } \\
\text { Infection } \\
\text { Arrhythmia } \\
\text { Coagulopathy } \\
\text { Pneumonia }\end{array}$ \\
\hline Notes & \\
\hline
\end{tabular}

\section{Risk of bias}

\begin{tabular}{l|l|l}
\hline Item & Authors' judgement & Description \\
\hline Allocation concealment? & Yes & $\begin{array}{l}\text { 'The investigators were blinded to the allocation. The statis- } \\
\text { tician and data systems manager controlled the randomisa- } \\
\text { tion protocol and were blinded to the site.' Adelson 2008b }\end{array}$ \\
\hline
\end{tabular}

\section{Adelson 2005 HYPO2}

\begin{tabular}{ll}
\hline Methods & Single centre, randomised, controlled trial. \\
\hline Participants & Patients less than 17 years of age, with a GOS of 8 or less. \\
\hline Interventions & $\begin{array}{l}\text { Hypothermia patients: Cooling to 32-33C for } 48 \text { hours. Passively rewarmed by } 1 \text { C every 3-4 hours. } \\
\text { Normothermia patients: no intervention/not reported. }\end{array}$ \\
\hline Outcomes & $\begin{array}{l}\text { ICP } \\
\text { CPP } \\
\text { Mortality } \\
\text { Infection } \\
\text { Arrhythmia } \\
\text { Coagulopathy } \\
\text { Pneumonia }\end{array}$
\end{tabular}




\section{Adelson 2005 HYPO2 (Continued)}

\begin{tabular}{|c|c|c|}
\hline Notes & \multicolumn{2}{|c|}{$\begin{array}{l}\text { The time between injury and randomisation was more than } 6 \text { hours. In some cases there was an unknown } \\
\text { time of injury (e.g. child abuse) }\end{array}$} \\
\hline \multicolumn{3}{|l|}{ Risk of bias } \\
\hline Item & Authors' judgement & Description \\
\hline Allocation concealment? & Yes & $\begin{array}{l}\text { 'The investigators were blinded to the allocation. The statis- } \\
\text { tician and data systems manager controlled the randomisa- } \\
\text { tion protocol and were blinded to the site.' Adelson } 2008 \mathrm{~b}\end{array}$ \\
\hline
\end{tabular}

Aibiki 2000

\begin{tabular}{|c|c|c|}
\hline Methods & \multicolumn{2}{|c|}{$\begin{array}{l}\text { Randomised controlled trial. } \\
\text { Four patients were excluded from the normothermic group after randomisation because of abdominal or } \\
\text { chest injuries }\end{array}$} \\
\hline Participants & \multicolumn{2}{|c|}{$\begin{array}{l}\text { Patients aged } 4 \text { to } 76 \text {, within } 8 \text { hours of traumatic brain injury. Glasgow coma scale score of } 8 \text { or less on } \\
\text { admission to emergency room }\end{array}$} \\
\hline Interventions & \multicolumn{2}{|c|}{$\begin{array}{l}\text { Hypothermia patients: Cooling to } 32-33 \mathrm{C} \text { within } 4 \text { hours on injury for } 3-4 \text { days. Rewarming at } 1 \mathrm{C} \text { per } \\
\text { day. } \\
\text { Normothermia patients: maintained at } 36-37 \mathrm{C} \text {. }\end{array}$} \\
\hline Outcomes & \multicolumn{2}{|c|}{$\begin{array}{l}\text { Death and GOS at } 6 \text { months. } \\
\text { Thromboxane A } 2 \text { and prostaglandin } \mathrm{I} 2 \text { levels during study. Complications during treatment }\end{array}$} \\
\hline Notes & \multicolumn{2}{|c|}{ GOS assessed by "independent neurosurgeon who were not aware of the study". p.3904 } \\
\hline \multicolumn{3}{|l|}{ Risk of bias } \\
\hline Item & Authors' judgement & Description \\
\hline Allocation concealment? & Unclear & $\begin{array}{l}\text { 'Patients were assigned randomly to each group.' p. } \\
3903 \text { No mention of allocation concealment }\end{array}$ \\
\hline
\end{tabular}

Biswas 2002

\begin{tabular}{l|l}
\hline Methods & Randomised controlled trial. \\
\hline Participants & Children up to 18 years old, with closed traumatic brain injury and a GCS of 8 or less \\
\hline Interventions & $\begin{array}{l}\text { Hypothermia patients }(\mathrm{n}=10): \text { cooled to } 32 \text { to } 34 \text { degrees Celsius for } 48 \text { hours, by cooling blanket placed } \\
\text { underneath the body. Rewarming over a period of } 12 \text { hours. } \\
\text { Control patients }(\mathrm{n}=11): \text { rectal temperature was maintained between } 36.5 \text { and } 37.5 \text { degrees Celsius }\end{array}$
\end{tabular}


Biswas 2002 (Continued)

\begin{tabular}{|c|c|c|}
\hline Outcomes & \multicolumn{2}{|c|}{$\begin{array}{l}\text { Death. } \\
\text { GOS at three, six and } 12 \text { months. } \\
\text { ICP and CPP. }\end{array}$} \\
\hline Notes & \multicolumn{2}{|c|}{$\begin{array}{l}\text { GOS assessed blind to allocation. } \\
\text { Analysis on an intention-to-treat basis. } \\
\text { Two patients in the hypo group were lost to follow-up and the end of the study period. ( } 2 / 10 \text { lost to } \\
\text { follow-up.) } \\
\text { Five patients in the control group were lost to follow-up at the end of the study period. ( } 5 / 11 \text { lost to } \\
\text { follow-up.) }\end{array}$} \\
\hline \multicolumn{3}{|l|}{ Risk of bias } \\
\hline Item & Authors' judgement & Description \\
\hline Allocation concealment? & Unclear & Not described. \\
\hline
\end{tabular}

\section{Clifton 1992}

\begin{tabular}{|c|c|c|}
\hline Methods & \multicolumn{2}{|c|}{ Randomised controlled trial. } \\
\hline Participants & \multicolumn{2}{|c|}{$\begin{array}{l}\text { Patients with GCS } 4-8 \text { with closed head injury but no major systemic injuries, in whom cooling could } \\
\text { begin within } 6 \text { hours of injury }\end{array}$} \\
\hline Interventions & \multicolumn{2}{|c|}{$\begin{array}{l}\text { Hypothermia patients: cooling to } 30-32 \mathrm{C} \text { for } 24 \text { hours using cooling blankets and iced saline stomach } \\
\text { lavage. Rewarming over a period of } 24 \text { hours. } \\
\text { Control patients: No active temperature management. }\end{array}$} \\
\hline Outcomes & \multicolumn{2}{|c|}{$\begin{array}{l}\text { Death and GOS at } 3 \text { months. } \\
\text { Complications during treatment phase. }\end{array}$} \\
\hline Notes & \multicolumn{2}{|c|}{ GOS was not assessed blind to treatment allocation. } \\
\hline \multicolumn{3}{|l|}{ Risk of bias } \\
\hline Item & Authors' judgement & Description \\
\hline Allocation concealment? & Yes & By 'sealed envelopes'. \\
\hline
\end{tabular}

\section{Clifton 1993}

\begin{tabular}{l|l}
\hline Methods & Randomised controlled trial. \\
\hline Participants & $\begin{array}{l}\text { Patients age } 16 \text { to } 60, \text { GCS } 4-7 \text { with closed head injury but no major systemic injuries, in whom cooling } \\
\text { could begin within } 6 \text { hours of injury }\end{array}$
\end{tabular}




\section{Clifton 1993 (Continued)}

\begin{tabular}{l|l}
\hline Interventions & $\begin{array}{l}\text { Hypothermia patients: cooling to 32-33C for } 48 \text { hours using cooling blankets. Rewarming over a period } \\
\text { of } 48 \text { hours. } \\
\text { Control patients: Cooling blankets were used to maintain body temperature at } 37 \mathrm{C} \text { for } 80 \text { hours }\end{array}$ \\
\hline Outcomes & $\begin{array}{l}\text { Death and GOS at } 3 \text { months. } \\
\text { Complications during treatment period. } \\
\text { ICP during treatment period. }\end{array}$ \\
\hline Notes & GOS assessed blind to treatment allocation. \\
\hline
\end{tabular}

\section{Risk of bias}

\begin{tabular}{lll}
\hline Item & Authors' judgement & Description \\
\hline Allocation concealment? & Yes & By 'sealed envelopes'. \\
\hline
\end{tabular}

Clifton 2001

\begin{tabular}{|c|c|c|}
\hline Methods & \multicolumn{2}{|c|}{ Randomised controlled trial. } \\
\hline Participants & \multicolumn{2}{|c|}{$\begin{array}{l}\text { Patients aged } 16 \text { to } 65 \text { with a non-penetrating head injury and a Glasgow coma scale of } 3 \text { to } 8 \text { after } \\
\text { resuscitation }\end{array}$} \\
\hline Interventions & \multicolumn{2}{|c|}{$\begin{array}{l}\text { Hypothermia patients: cooling to } 32.5-34 \mathrm{C} \text { for } 48 \text { hours using ice, cold gastric lavage, unwarmed ventilator } \\
\text { gases, and then temperature control pads. Rewarming at rate of up to } 0.5 \mathrm{C} \text { in } 2 \text { hours. } \\
\text { Control: Body temperature maintained at } 37 \mathrm{C} \text {. }\end{array}$} \\
\hline Outcomes & \multicolumn{2}{|c|}{$\begin{array}{l}\text { Death and GOS at } 6 \text { months. } \\
\text { ICP monitored during treatment. } \\
\text { Nine neurobehavioural and neuropsychological scales at } 6 \text { months }\end{array}$} \\
\hline Notes & \multicolumn{2}{|c|}{$\begin{array}{l}\text { GOS was assessed blind to treatment allocation. } \\
\text { Outcome data missing for } 7 \text { patients, and not presented for } 17 \text { patients whose entry details were incomplete }\end{array}$} \\
\hline \multicolumn{3}{|l|}{ Risk of bias } \\
\hline Item & Authors' judgement & Description \\
\hline Allocation concealment? & Yes & $\begin{array}{l}\text { Allocation concealment unclear, but report states that "only the study } \\
\text { biostatistician was aware of each patient's treatment group assignment" }\end{array}$ \\
\hline
\end{tabular}


Hashiguchi 2003

\begin{tabular}{|c|c|c|}
\hline Methods & \multicolumn{2}{|c|}{ Randomised controlled trial. Allocation method not stated. } \\
\hline Participants & \multicolumn{2}{|c|}{$\begin{array}{l}\text { Participants age } 10 \text { years or older, with a GCS of } 8 \text { or less, 'who required continuous infusion of barbiturates } \\
\text { to control intracranial hypertension.' p. } 1055\end{array}$} \\
\hline Interventions & \multicolumn{2}{|c|}{$\begin{array}{l}\text { Hypothermia patients }(\mathrm{n}=9) \text { : intracranial temperature in the lateral ventricle was maintained at } 33.5 \text { to } \\
34.5 \text { degrees Celsius for } 48 \text { hours, by water circulating blankets above and below the body. Rewarming } \\
\text { over a period of } 3 \text { days, by } 1 \text { degree Celsius each day. } \\
\text { Control patients }(\mathrm{n}=8) \text { : intracranial temperature was maintained between } 36.5 \text { and } 37.5 \text { degrees Celsius } \\
\text { for } 5 \text { days, by water circulating blankets above and below the body } \\
\text { Barbiturates were given to both groups at } 6 \text { to } 8 \mathrm{mg} / \mathrm{kg} / \mathrm{h} \text { for the first } 48 \text { hours, then at } 2 \mathrm{mg} / \mathrm{kg} / \mathrm{h} \text { for } 3 \\
\text { days }\end{array}$} \\
\hline \multicolumn{3}{|l|}{ Outcomes } \\
\hline \multicolumn{3}{|l|}{ Notes } \\
\hline \multicolumn{3}{|l|}{ Risk of bias } \\
\hline Item & Authors' judgement & Description \\
\hline Allocation concealment? & Unclear & Not described. \\
\hline \multicolumn{3}{|l|}{ Hirayama 1994} \\
\hline Methods & \multicolumn{2}{|c|}{ Randomised controlled trial. Allocation method not stated. } \\
\hline Participants & \multicolumn{2}{|c|}{ Patients age 18 to 81 , GCS 3-7 with closed head injury. Hypothermia started within 6 hours of injury } \\
\hline Interventions & \multicolumn{2}{|c|}{$\begin{array}{l}\text { Hypothermia patients: cooling to } 32-33 \mathrm{C} \text { for } 48 \text { hours using cooling blankets. Rewarming over a period } \\
\text { of } 48 \text { hours. } \\
\text { Control patients: Not stated. }\end{array}$} \\
\hline Outcomes & \multicolumn{2}{|c|}{$\begin{array}{l}\text { Death and GOS at } 3 \text { months. } \\
\text { ICP during treatment period. }\end{array}$} \\
\hline Notes & \multicolumn{2}{|c|}{ Blinding of outcome assessment not stated. } \\
\hline \multicolumn{3}{|l|}{ Risk of bias } \\
\hline Item & Authors' judgement & Description \\
\hline Allocation concealment? & Unclear & Not described. \\
\hline
\end{tabular}


Ishikura 1998

\begin{tabular}{|c|c|c|}
\hline Methods & \multicolumn{2}{|c|}{ Randomised controlled trial. Allocation by 'random sampling' } \\
\hline Participants & \multicolumn{2}{|l|}{ Patients with GCS 3-8 with closed head injury. } \\
\hline Interventions & \multicolumn{2}{|l|}{ 'Moderate hypothermia' without any details. } \\
\hline Outcomes & \multicolumn{2}{|l|}{$\begin{array}{l}\text { Thrombopoetin levels during treatment. } \\
\text { Deaths in hypothermia arm only. }\end{array}$} \\
\hline Notes & \multicolumn{2}{|l|}{ Abstract only. } \\
\hline \multicolumn{3}{|l|}{ Risk of bias } \\
\hline Item & Authors' judgement & Description \\
\hline Allocation concealment? & Unclear & $\begin{array}{l}\text { '11 patients with severe closed head injuries were } \\
\text { divided into two groups by random sampling.' No } \\
\text { information provided on allocation concealment }\end{array}$ \\
\hline
\end{tabular}

Jiang 2000

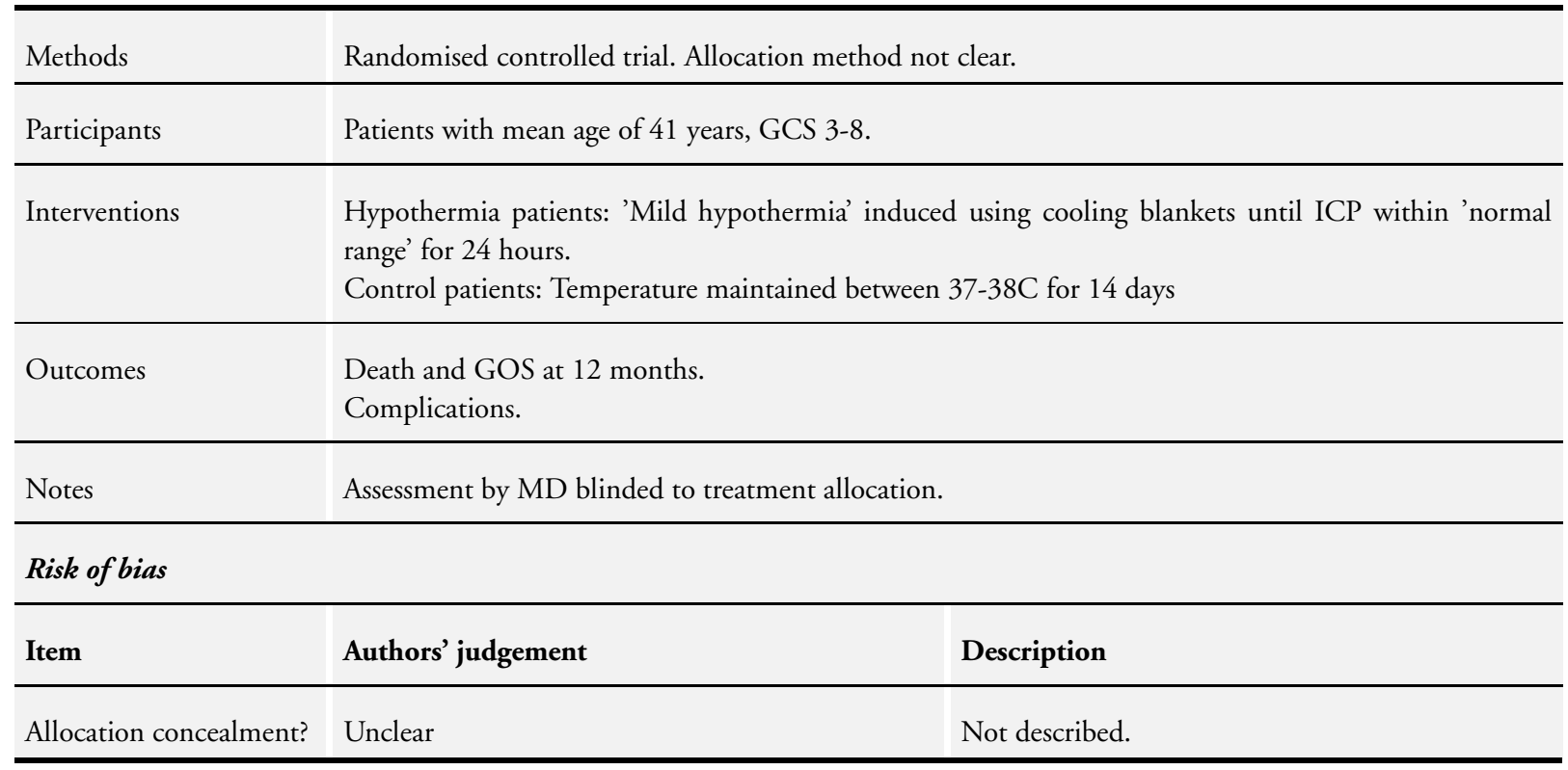

Marion 1997

\begin{tabular}{ll}
\hline Methods & Randomised controlled trial. Allocation by 'sealed envelopes' \\
\hline Participants & $\begin{array}{l}\text { Patients age } 16 \text { to } 75, \text { GCS 3-7 with closed head injury, in whom cooling could begin within } 6 \text { hours of } \\
\text { injury }\end{array}$
\end{tabular}




\section{Marion 1997 (Continued)}

\begin{tabular}{|c|c|c|}
\hline Interventions & \multicolumn{2}{|c|}{$\begin{array}{l}\text { Hypothermia patients: Cooling to } 32-33 \mathrm{C} \text { for } 24 \text { hours using cooling blankets and nasogastric lavage. } \\
\text { Rewarming over a period of } 12 \text { hours. } \\
\text { Control patients: Active management of temperature to } 37-38.5 \mathrm{C} \text { during five day treatment period }\end{array}$} \\
\hline Outcomes & \multicolumn{2}{|c|}{$\begin{array}{l}\text { Death and GOS at } 3,6 \text { and } 12 \text { months. } \\
\text { ICP and CPP values during treatment phase. } \\
\text { Complications for subset. }\end{array}$} \\
\hline Notes & \multicolumn{2}{|c|}{ GOS assessment by psychiatrist blinded to treatment allocation } \\
\hline \multicolumn{3}{|l|}{ Risk of bias } \\
\hline Item & Authors' judgement & Description \\
\hline Allocation concealment? & Yes & $\begin{array}{l}\text { 'Using a block-randomization scheme, we assigned } \\
\text { patients with a Glasgow coma score of } 3 \text { or } 4 \text { to a } \\
\text { treatment group separately from those with a score } \\
\text { of } 5 \text { to } 7 \text { by choosing among equal numbers of sealed } \\
\text { envelopes containing the group assignments.' p. } 540\end{array}$ \\
\hline
\end{tabular}

Meissner 1998

\begin{tabular}{|c|c|c|}
\hline Methods & \multicolumn{2}{|c|}{ Randomised controlled trial. } \\
\hline Participants & \multicolumn{2}{|c|}{ Patients with severe blunt head injury, in whom cooling could begin within 8 hours of injury } \\
\hline Interventions & \multicolumn{2}{|c|}{$\begin{array}{l}\text { Hypothermia patients: Cooling to } 32-33 \mathrm{C} \text { for } 48 \text { hours. } \\
\text { Control patients: Temperature maintained at } 36-37 \mathrm{C} \text {. }\end{array}$} \\
\hline Outcomes & \multicolumn{2}{|l|}{$\begin{array}{l}\text { Death. } \\
\text { Infections. }\end{array}$} \\
\hline Notes & \multicolumn{2}{|c|}{ GOS assessed at 6 months by non-blinded assessor, but not yet available } \\
\hline \multicolumn{3}{|l|}{ Risk of bias } \\
\hline Item & Authors' judgement & Description \\
\hline Allocation concealment? & Yes & By 'sealed envelopes'. \\
\hline
\end{tabular}


Meissner 2003a

\begin{tabular}{l|l}
\hline Methods & Randomised controlled trial. \\
\hline Participants & Patients with severe blunt head injury. Intervention was started within 8 hours of injury \\
\hline Interventions & $\begin{array}{l}\text { Hypothermia patients: Cooling to 32-33C for } 48 \text { hours. } \\
\text { Control patients: Temperature maintained at 36-37C. }\end{array}$ \\
\hline Outcomes & $\begin{array}{l}\text { Heart rate. } \\
\text { Mean blood pressure. } \\
\text { Plasma cortisol. }\end{array}$ \\
\hline Notes & $\begin{array}{l}\text { Primary outcome of study was moderate hypothermia on the cardiovascular and cortisol response in severe } \\
\text { head injury } \\
\text { No mortality data reported. }\end{array}$ \\
\hline
\end{tabular}

Risk of bias

\begin{tabular}{|c|c|c|}
\hline Item & Authors' judgement & Description \\
\hline Allocation concealment? & Unclear & Not described. \\
\hline
\end{tabular}

Meissner 2003b

\begin{tabular}{|c|c|c|}
\hline Methods & \multicolumn{2}{|c|}{ Randomised controlled trial. } \\
\hline Participants & \multicolumn{2}{|c|}{$\begin{array}{l}\text { Patients aged } 18 \text { or older, with severe closed head injury with a GCS }<=9 \text {. Intervention was started within } \\
8 \text { hours of injury }\end{array}$} \\
\hline Interventions & \multicolumn{2}{|c|}{$\begin{array}{l}\text { Hypothermia patients: Cooling to } 32-33 \mathrm{C} \text { for } 24-48 \text { hours. Cooling was by water blankets and forced } \\
\text { air. } \\
\text { Control patients: Temperature maintained at } 36-37 \mathrm{C} \text {. }\end{array}$} \\
\hline Outcomes & \multicolumn{2}{|l|}{$\begin{array}{l}\text { TSH } \\
\text { TT4 } \\
\text { FT4 } \\
\text { TT3 } \\
\text { FT3 } \\
\text { RT3 }\end{array}$} \\
\hline Notes & \multicolumn{2}{|c|}{ This study examined thyroid hormone response in relation to therapeutic hypothermia } \\
\hline \multicolumn{3}{|l|}{ Risk of bias } \\
\hline Item & Authors' judgement & Description \\
\hline Allocation concealment? & Unclear & Not described. \\
\hline
\end{tabular}


Qiu 2007

\begin{tabular}{|c|c|c|}
\hline Methods & \multicolumn{2}{|c|}{ Randomised, controlled, double-blind trial. } \\
\hline Participants & \multicolumn{2}{|c|}{ Patients $18-65$ years old with traumatic brain injury with a Glasgow Coma Scale score of 8 or less } \\
\hline Interventions & \multicolumn{2}{|c|}{$\begin{array}{l}\text { Hypothermia patients: Cooling to } 33-35 \mathrm{C} \text { for } 4 \text { days after craniotomy, using a cooling blanket and cooling } \\
\text { head cap with circulating water at } 4 \mathrm{C} \text {. 'Natural' rewarming. } \\
\text { Normothermia patients: cooling not used. }\end{array}$} \\
\hline Outcomes & \multicolumn{2}{|c|}{$\begin{array}{l}\text { Mortality. } \\
\text { ICP. } \\
\text { Serum superoxide dismutase level. } \\
\text { Glasgow Outcome Scale at } 1 \text { year post-intervention. }\end{array}$} \\
\hline \multicolumn{3}{|l|}{ Notes } \\
\hline \multicolumn{3}{|l|}{ Risk of bias } \\
\hline Item & Authors' judgement & Description \\
\hline Allocation concealment? & Yes & $\begin{array}{l}\text { 'Allocation and randomization was concealed so that the } \\
\text { study investigators were not aware to which group the pa- } \\
\text { tient would be assigned, and the allocation sequence was } \\
\text { protected until assignment.' p. } 230\end{array}$ \\
\hline
\end{tabular}

\section{Shiozaki 1993}

\begin{tabular}{|c|c|c|}
\hline Methods & \multicolumn{2}{|c|}{ Randomised controlled trial. } \\
\hline Participants & \multicolumn{2}{|c|}{$\begin{array}{l}\text { Patients age } 10 \text { or over, GCS } 8 \text { or less with head injury, who 'required continuous infusion of barbiturates } \\
\text { to control intracranial hypertension'. p. } 363\end{array}$} \\
\hline Interventions & \multicolumn{2}{|c|}{$\begin{array}{l}\text { Hypothermia patients: cooling to } 33.5-34.5 \mathrm{C} \text { using water-circulating cooling blankets for a minimum of } \\
48 \text { hours and until ICP was below } 20 \mathrm{mmHg} \text { for } 24 \text { hours. Rewarming over a period of } 24 \text { hours. } \\
\text { Control patients: No active temperature management. }\end{array}$} \\
\hline Outcomes & \multicolumn{2}{|c|}{$\begin{array}{l}\text { Death and GOS at } 6 \text { months. } \\
\text { Pneumonia. } \\
\text { Complications during treatment. } \\
\text { ICP and CPP values during treatment period for hypothermic arm only }\end{array}$} \\
\hline Notes & \multicolumn{2}{|c|}{ GOS assessed blind to treatment allocation. } \\
\hline \multicolumn{3}{|l|}{ Risk of bias } \\
\hline Item & Authors' judgement & Description \\
\hline Allocation concealment? & Unclear & Not described. \\
\hline
\end{tabular}


Shiozaki 1999

\begin{tabular}{|c|c|c|}
\hline Methods & \multicolumn{2}{|c|}{$\begin{array}{l}\text { Randomised controlled trial. Allocation concealment not clear. } \\
\text { No loss to follow up. }\end{array}$} \\
\hline Participants & \multicolumn{2}{|c|}{$\begin{array}{l}\text { Patients age } 10 \text { and above with traumatic brain injury, a Glasgow coma scale of } 8 \text { or less, and 'who required } \\
\text { continuous infusion of barbiturate medication to control intracranial hypertension.' p. } 185\end{array}$} \\
\hline Interventions & \multicolumn{2}{|c|}{$\begin{array}{l}\text { Hypothermia patients: cooling to } 33.5-34.5 \mathrm{C} \text { for } 48 \text { hours, using water circulating blankets. Rewarming } \\
\text { at } 1 \mathrm{C} \text { per day. } \\
\text { Normothermia patients: maintained at } 36.5-37.5 \mathrm{C} \text {. }\end{array}$} \\
\hline Outcomes & \multicolumn{2}{|c|}{$\begin{array}{l}\text { Death and GOS at } 6 \text { months. } \\
\text { Complications. }\end{array}$} \\
\hline Notes & \multicolumn{2}{|c|}{ Blinding of outcome assessment not stated. } \\
\hline \multicolumn{3}{|l|}{ Risk of bias } \\
\hline Item & Authors' judgement & Description \\
\hline Allocation concealment? & Unclear & Not described. \\
\hline
\end{tabular}

\section{Shiozaki 2001}

\begin{tabular}{|c|c|c|}
\hline Methods & \multicolumn{2}{|c|}{$\begin{array}{l}\text { Randomised controlled trial. } \\
\text { Allocation concealment not clear. } \\
\text { No loss to follow up. }\end{array}$} \\
\hline Participants & \multicolumn{2}{|c|}{$\begin{array}{l}\text { Patients with traumatic brain injury, a Glasgow coma scale of } 8 \text { or less, and 'in whom ICP was maintained } \\
\text { below } 25 \mathrm{mmHg} \text { by conventional therapies'. p. } 50\end{array}$} \\
\hline Interventions & \multicolumn{2}{|c|}{$\begin{array}{l}\text { Hypothermia patients: Cooling to } 33.5-34.5 \mathrm{C} \text { for } 48 \text { hours, using cooling blankets and gastric lavage. } \\
\text { Rewarming at } 1 \mathrm{C} \text { per day. } \\
\text { Normothermia patients: maintained at } 36.5-37.5 \mathrm{C} \text {. }\end{array}$} \\
\hline Outcomes & \multicolumn{2}{|c|}{$\begin{array}{l}\text { Death and GOS at } 3 \text { months. } \\
\text { Complications }\end{array}$} \\
\hline Notes & \multicolumn{2}{|c|}{ Blinding of outcome assessment not stated. } \\
\hline \multicolumn{3}{|l|}{ Risk of bias } \\
\hline Item & Authors' judgement & Description \\
\hline Allocation concealment? & Unclear & Not described. \\
\hline
\end{tabular}


Smrcka 2005

\begin{tabular}{|c|c|c|}
\hline Methods & \multicolumn{2}{|c|}{$\begin{array}{l}\text { Randomised controlled trial - randomisation method not described. } \\
\text { No loss to follow up described. }\end{array}$} \\
\hline Participants & \multicolumn{2}{|c|}{$\begin{array}{l}\text { Patients with traumatic brain injury with a Glasgow Coma Scale score of } 8 \text { or less, who were up to age } 61 \\
\text { years of age }\end{array}$} \\
\hline Interventions & \multicolumn{2}{|c|}{$\begin{array}{l}\text { Hypothermia }(n=37) \text { : surface cooling to } 34 \mathrm{C} \text { for } 72 \text { hours. Temperature measured in urinary bladder } \\
\text { Passive rewarming } \\
\text { Normothermia }(n=35) \text { : cooling not used. }\end{array}$} \\
\hline Outcomes & \multicolumn{2}{|c|}{$\begin{array}{l}\text { ICP } \\
\mathrm{CPP} \\
\mathrm{SvjO}_{2} \text { (jugular bulb oxygen saturation) } \\
\text { GOS }\end{array}$} \\
\hline \multicolumn{3}{|l|}{ Notes } \\
\hline \multicolumn{3}{|l|}{ Risk of bias } \\
\hline Item & Authors' judgement & Description \\
\hline Allocation concealment? & Unclear & Not described. \\
\hline
\end{tabular}

Yan 2001

\begin{tabular}{l|l}
\hline Methods & $\begin{array}{l}\text { Randomised controlled trial. } \\
\text { Allocation concealment not described. } \\
\text { No loss to follow up described. }\end{array}$ \\
\hline Participants & $\begin{array}{l}\text { Patients with traumatic brain injury within } 10 \text { hours of injury and a Glasgow Coma Scale of } 3 \text { to } 8 \text { on } \\
\text { initial assessment }\end{array}$ \\
\hline Interventions & $\begin{array}{l}\text { Hypothermia patients: Cooling to 32-34C for 3-5 days, using a cooling bed and, in some, ice blocks. } \\
\text { 'Natural' rewarming. } \\
\text { Normothermia patients: cooling not used. }\end{array}$ \\
\hline Outcomes & $\begin{array}{l}\text { Death, follow up period unclear. } \\
\text { Neuroelectrophysiological measurements. }\end{array}$ \\
\hline Notes & Blinding of outcome assessment not stated.
\end{tabular}

\section{Risk of bias}

\begin{tabular}{|c|c|c|}
\hline Item & Authors' judgement & Description \\
\hline Allocation concealment? & Unclear & Not described. \\
\hline
\end{tabular}


Zhang 2000

\begin{tabular}{|c|c|c|}
\hline Methods & \multicolumn{2}{|c|}{$\begin{array}{l}\text { Randomised controlled trial. } \\
\text { Allocation concealment not described. No loss to follow up mentioned }\end{array}$} \\
\hline Participants & \multicolumn{2}{|c|}{$\begin{array}{l}\text { Patients aged under } 65 \text { with traumatic brain injury and a Glasgow Coma Scale of 3-8 on admission to } \\
\text { hospital }\end{array}$} \\
\hline Interventions & \multicolumn{2}{|c|}{$\begin{array}{l}\text { Hypothermia patients: Cooling to } 32-33 \mathrm{C} \text { for } 3-8 \text { days. } \\
\text { Normothermia patients: temperature not stated. }\end{array}$} \\
\hline Outcomes & \multicolumn{2}{|c|}{ Death, follow up period unclear. } \\
\hline Notes & \multicolumn{2}{|c|}{ Blinding of outcome assessment not stated. } \\
\hline \multicolumn{3}{|l|}{ Risk of bias } \\
\hline Item & Authors' judgement & Description \\
\hline Allocation concealment? & Unclear & Not described. \\
\hline
\end{tabular}

Characteristics of excluded studies [ordered by study ID]

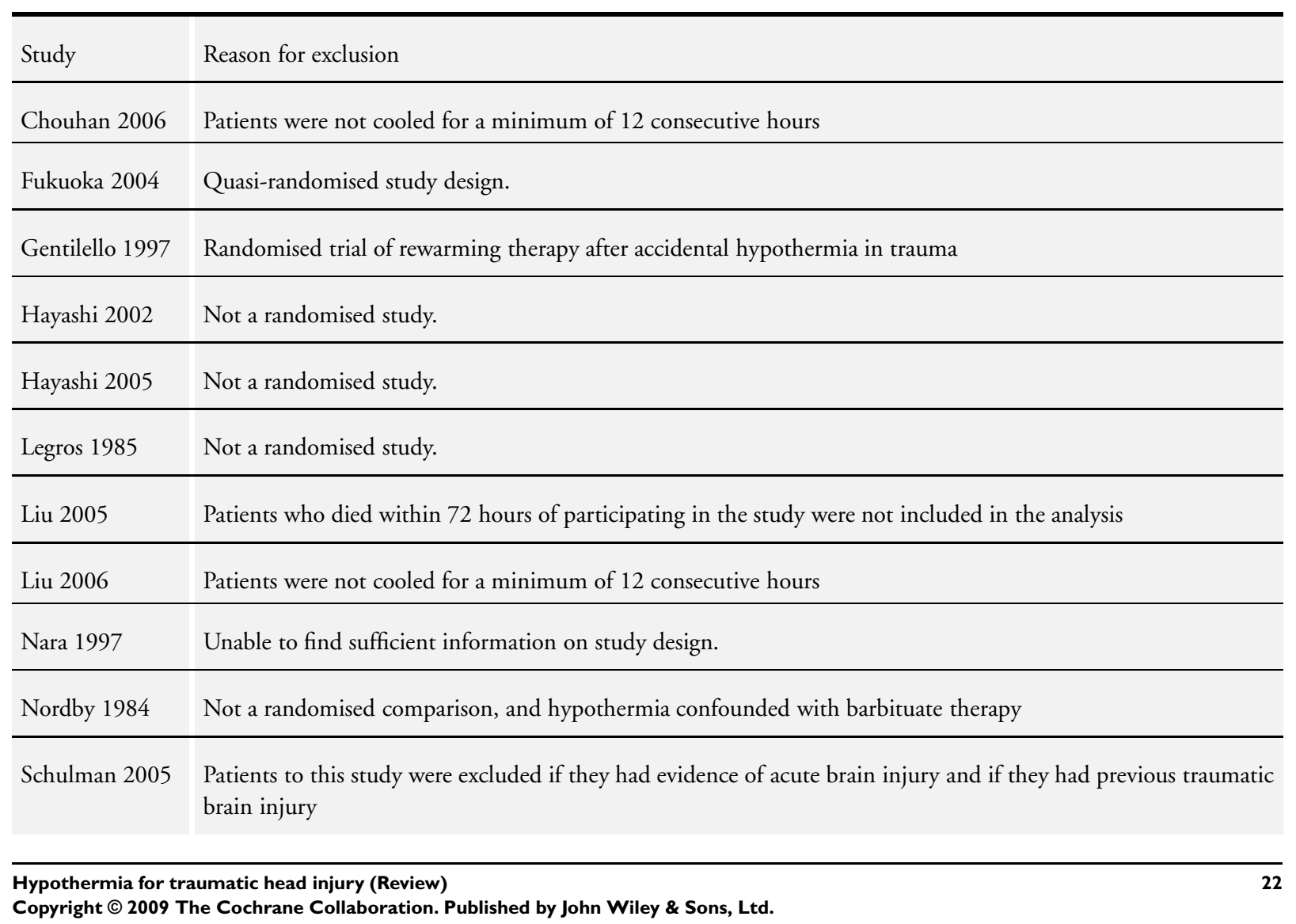


(Continued)

\begin{tabular}{ll} 
Shen 2000 & Not a randomised trial. \\
\hline Wusi 2006 & Not a randomised trial. \\
\hline Yamagami 1997 & Not a randomised trial; hypothermia group GCS 4-6, normothermia group GCS 8-10 \\
\hline
\end{tabular}

\section{Characteristics of studies awaiting assessment [ordered by study ID]}

\section{Chen 2001}

Methods

Participants

Interventions

Outcomes

Notes Awaiting clarification from authors about method of randomisation and allocation concealment

Guo 2004

Methods

Participants

Interventions

Outcomes

Notes Awaiting clarification from authors about method of randomisation and allocation concealment

Hutchison 2008

Methods

Participants

Interventions

Outcomes

Notes Data to be included in this review for issue 2, 2009. 
Mrlian 2006

Methods

Participants

Interventions

\section{Outcomes}

Notes Awaiting clarification from authors about method of randomisation and allocation concealment

Qiu 2005

Methods

Participants

Interventions

Outcomes

Notes Awaiting clarification from authors about method of randomisation and allocation concealment

Qiu 2006

Methods

Participants

Interventions

Outcomes

Notes Awaiting clarification from authors about method of randomisation and allocation concealment

\section{Wang 2005}

Methods

Participants

Interventions

Outcomes

Notes Awaiting clarification from authors about method of randomisation and allocation concealment 
Wang 2007

Methods

Participants

Interventions

Outcomes

Notes Awaiting clarification from authors about method of randomisation and allocation concealment

\section{Xia 2005}

Methods

Participants

Interventions

Outcomes

Notes Awaiting clarification from authors about method of randomisation and allocation concealment

\section{Yan 2007}

Methods

Participants

Interventions

Outcomes

Notes Awaiting clarification from authors about method of randomisation and allocation concealment

\section{Zhi 2003}

Methods

Participants

Interventions

Outcomes

Notes Awaiting clarification from authors about method of randomisation and allocation concealment 
Characteristics of ongoing studies [ordered by study ID]

\section{Adelson 2007}

\begin{tabular}{|c|c|}
\hline Trial name or title & Pediatric traumatic brain injury consortium: hypothermia. \\
\hline Methods & Treatment, Randomized, Single Blind (outcome assessor), single group assignment, efficacy study \\
\hline Participants & TBI patients under 16 years of age, with a GCS $</=8$. \\
\hline Interventions & Patients in the treatment arm will be cooled to $32-33 \mathrm{C}$ for 48 hours and then slowly rewarmed \\
\hline Outcomes & $\begin{array}{l}\text { - To determine the effect of induced moderate hypothermia }(32-33 \mathrm{C}) \text { after severe TBI in children on } \\
\text { mortality. } \\
\text { - To determine the effect of hypothermia after severe TBI in children on global function and } \\
\text { neurocognitive outcomes in the areas of intellectual ability/development, memory and learning, and } \\
\text { behaviour. } \\
\text { - To determine the effect of hypothermia after severe TBI in children of different age ranges (<6y and } 6 \\
\text { to <16y) on mortality and } 6 \text { and } 12 \text { months functional and neurocognitive outcomes. } \\
\text { - To determine the effect of hypothermia after severe TBI in children on reducing intracranial } \\
\text { hypertension and maintaining adequate cerebral perfusion pressure (CPP). }\end{array}$ \\
\hline Starting date & November 2007 \\
\hline Contact information & $\begin{array}{l}\text { P. David Adelson +1(412)692-6347 david.adelson@chp.edu } \\
\text { S. Danielle Brown +1(412)692-8794 brownds2@upmc.edu }\end{array}$ \\
\hline Notes & Phase III Clinical Trial. \\
\hline
\end{tabular}

Clifton 2002

\begin{tabular}{ll}
\hline Trial name or title & National Acute Brain Injury Study: Hypothermia II (NABISH II) \\
\hline Methods & $\begin{array}{l}\text { Randomized, prospective, multi-center trial. Hypothermia for } 48 \text { hours, begun within } 6 \text { hours of severe brain } \\
\text { injury }\end{array}$ \\
\hline Participants & $\begin{array}{l}\text { Patients aged } 16 \text { to } 45 \text { years inclusive who have a closed head injury, present to the Emergency Department } \\
\text { with a Glasgow Coma Score between } 3-8 \text {, have a body temperature (bladder or rectal) of } 35 \text { degrees Celsius } \\
\text { or less at admission, and an Abbreviated Injury Score (AIS) of } 4 \text { or less for the rest of the body }\end{array}$ \\
\hline Interventions & $\begin{array}{l}\text { The patients will be randomly allocated to either the hypothermia group or the normothermia group. A } \\
\text { cooling suit will be used to cool the hypothermia patients down to a body temperature of } 33 \text { degrees Celsius. } \\
\text { This temperature of } 33 \text { degrees will be maintained in the hypothermia patients for } 48 \text { hours. After } 48 \text { hours, } \\
\text { the study nurses will gradually re-warm the hypothermia patients no faster than one degree every four hours. } \\
\text { This takes at least } 16 \text { hours sometimes longer depending upon the stability of the patient's vital signs. The } \\
\text { control group - normothermia will be allowed to re-warm gradually upon arrival to the hospital with no } \\
\text { medical intervention to raise or lower the body temperature }\end{array}$
\end{tabular}

Hypothermia for traumatic head injury (Review) 


\begin{tabular}{|c|c|}
\hline Outcomes & $\begin{array}{l}\text { Mortality and GOS. ICP and complications. } \\
\text { Outcomes will be measured } 6 \text { months post injury by Harvey Levin, MD at Baylor College of Medicine. The } \\
\text { personnel conducting outcome measurements will be blinded to the patient's assigned treatment protocol } \\
\text { (whether hypothermia or normothermia) }\end{array}$ \\
\hline Starting date & $4 / 1 / 02-6 / 30 / 08$ \\
\hline Contact information & $\begin{array}{l}\text { Guy L. Clifton, MD } \\
\text { Chairman Neurosurgery Dept., University of Texas Medical School } \\
6431 \text { Fannin St., Suite } 7.148 \\
\text { Houston, TX } 77030 \\
\text { 713-500-6135 } \\
\text { guy.l.clifton@uth.tmc.edu } \\
\text { Emmy R. Miller, RN, PhD, Co-investigator NABISH II } \\
\text { Associate Professor of Neurosurgery } \\
\text { University of Texas Medical School, Houston, TX } \\
\text { 6431 Fannin St., Suite 7.148 } \\
\text { Houston, TX 77030 } \\
\text { 713-500-6145 } \\
\text { Emmy.R.Miller@uth.tmc.edu }\end{array}$ \\
\hline Notes & $\begin{array}{l}\text { There are other study sites participating in NABISH II. } \\
\text { They are: } \\
\text { University of Pittsburgh, Duke University, University of California at Los Angeles, University of California } \\
\text { at Sacramento, University of California at San Francisco, University of Virginia at Fairfax, University of } \\
\text { Cincinnati, University of Mississippi at Jackson }\end{array}$ \\
\hline
\end{tabular}

